\title{
PENGEMBANGAN EPISTEMOLOGI ILMU HUKUM BERBASIS TRANSENDENTAL
}

\author{
Sigit Sapto Nugroho \\ Fakultas Hukum Universitas Merdeka Madiun \\ e-mail: sigit.nugroho26@gmail.com
}

\begin{abstract}
ABSTRAK
Pandangan positivisme memandang dimensi spiritual dengan segala perspektifnya seperti agama, etika dan moralitas diletakkan sebagai bagian yang terpisah dari satu kesatuan pembangunan peradaban modern. Hukum modern dalam perkembangannya telah kehilangan unsur yang esensial, yakni nilai-nilai spiritual sehingga masyarakaat modern telah terjadi krisis dalam memaknai makna hidup di dunia atau the crisis of meaning. Epistimologi ilmu hukum berbasis transendental menekankan pada pendekatan integrasi antara sains dan nilai-nilai dalam berbagai pandangan. Basis ilmu hukum transendental memahami manusia dan kehidupannya dalam wujud yang utuh (holistik), tidak semata bersifat materi tetapi juga jiwanya. Manusia menggali, mengolah dan merumuskan ilmu dengan tujuan tidak semata untuk ilmu tetapi juga untuk kebijakan, kemaslahatan masyarakat luas, dengan ridha, dan kasih sayang Allah.
\end{abstract}

Kata Kunci: spiritual, epistemologi ilmu hukum, basis transendental.

\begin{abstract}
The views of positivism, the spiritual dimension by all perspectives such as religion, ethics and morality are put as a separate part of the unitary construction of modern civilization. Modern law in its development has lost an essential element, namely the spiritual values that modern masyarakaat have a crisis in defining the meaning of life in the world (the crisis of meaning). Epistimologi transcendental science of law based approach emphasizes the integration between science and values in various views. Legal science base transcendental understand people and their life in an intact form (holistic), not merely material nature but also his soul. Human explore, process and formulate science with the aim not only to science but also to the policy, the benefit of society at large, by the blessing and mercy of Allah.
\end{abstract}

Keywords: spiritual, epistemology law, basis of transcendental.

\section{PENDAHULUAN}

Perkembangan ilmu hukum modern sebagai akibat konsekuensi dari perubahan bentuk menuju negara modern menjadi arus globalisasi yang tidak terelakkan. Ilmu pengetahuan modern telah mempengaruhi terbentuknya negara modern dan negara modern menuntut mainstream ilmu hukum yang modern untuk menata kehidupan negara. Ilmu hukum modern yang mendasarkan pada objektivitas, empirisitas dan rasionalitas menjadi suatu tatanan yang tersistematis, prosedural dan formal. Ilmu hukum modern yang berkembang selama ini dapat dipahami merupakan sebagai bentuk positivisme. Berangkat dari perkembangan ilmu hukum modern positivisme yang terjadi di Indonesia sekarang ini menunjukkan bentuk tipologi pemahaman ilmu hukum yang positivisme.

Pemahaman ilmu hukum positivisme yang hanya mengutamakan kebenaran objektif, empiris dan logis yang telah tersistematis, prosedur dan formal yang terdapat dalam tulisan teks belaka serta tidak berusaha menggali makna yang tersembunyi dibalik tulisan teks itu akan menghilangkan inti hakekat yang sebenarnya merupakan problematika yang berkembang, sehingga mencoba menggali pemikiran ke arah pemikiran tidak hanya aras lahir tetapi juga aras batin.

Pemikiran-pemikiran tentang alternatif epistemologi ilmu hukum di Indonesia terus dilakukan seiring perkembangan ilmu pengetahuan. Keinginan untuk beranjak dari pemikiran ilmu 
hukum modern positivisme ke arah pemikiran ilmu hukum postmodernisme mulai terasa di dunia hukum. Kerinduan akan kedamaian jiwa, batiniah, nilai-nilai agama dan Tuhan menjadi faktor yang kuat mempengaruhi. Pemikiran yang berparadigma pembaruan terhadap ilmu hukum tersebut yang dimaksudkan sebagai pemikiran ilmu hukum post positivistik. Ilmu hukum post positivistik berusaha untuk menampilkan konsep yang lain dan berbeda dari ilmu hukum modern positivistik. Boleh dikatakan ilmu dari waktu ke waktu mengalami perubahan yang biasanya dimulai dari perubahan dalam paradigma yang digunakan.

Postmodernisme mulai mengangkat hal-hal yang sifatnya irasional (emosi, perasaan, intuisi, pengalaman personal, spekulasi), moral, dan spiritual sebagai bagian integral dalam memahami kajian/ persoalan keilmuan. Pemikiran hukum yang dianggap tidak puas (kritis bahkan memberontak) terhadap terhadap paradigma hukum modern yang liberal dan mapan yang dikategorikan sebagai pemikiran postmodernisme.

Alasan yang mendasar bahwa ilmu dalam dunia modern yang selama ini dianggap segala-galanya, ternyata tidak mampu memecahkan persoalanpersoalan hidup dan kehidupan. Ilmu dianggap kejayaannya telah berakhir atau the end of science. Secara aksiologis ilmu sudah tidak ada lagi manfaatnya dan dianggap tidak mampu menyelesaikan persoalan dalam hidup masyarakat. Ilmu dianggap dominan ikut campur tangan dalam segala sektor kehidupan tetapi pada saat yang bersamaan ilmu telah menimbulkan berbagai persoalan. Dalam alam modernisme, perspektif transendental dengan segala aspeknya seperti keagamaan, etika, dan moral diletakkan sebagai bagian yang terpisah dari satu kesatuan pembangunan peradaban modern. Karena itu, hukum modern dalam perkembangannya telah kehilangan unsur yang esensial yang berupa nilai transedental. Hal ini terjadi sebagai akibat cara berpikir yang didasari dari pandangan keduniaan yang diurus oleh kaisar dan keagamaan yang diserahkan pada tokoh agama (pendeta, rahib dan ulama). ${ }^{1}$

Padahal sebenarnya dimensi transendental dalam pospositivisme dapat dilihat pada jangkauan yang

${ }^{1}$ Absori, "Epistimologi Ilmu Hukum Transendental dan Implementasinya dalam Pengembangan Program Doktor Ilmu Hukum", Prosiding, Seminar Nasional di Universitas Muhammadiyah, Surakarta, 11 April 2015. lebih luas yang berupa agama, etika, dan moralitas yang tidak lagi dipahami dalam satu aspek saja, yaitu aspek yang terkait dengan persoalan teologi dan keinginan semata, tapi lebih dari itu persoalan nilainilai tersebut dapat didialogkan dengan persoalan pengembangan keilmuan, sosial, budaya, ekonomi dan hukum.

Adanya krisis masyarakat barat yang dianggap sebagai kegagalan peradaban modern karena pemikiran modern telah memisahkan spiritualisme dengan segala aspek dalam satu kesatuan kehidupan dan pembangunan peradaban manusia. Untuk itu menurut Suhirman Djirman, untuk memahami hidup dan kehidupan peradaban manusia yang kompleks ilmu (pemikiran) manusia perlu dikonstruksi ulang dengan pendekatan spiritual. Spiritual bukan sekedar institusi, ilmu modern ternyata tidak mampu menjangkau dimensi spiritual, sebab ilmu modern mengandalkan rasio bersifat analitik, logis dan sistemik (Newtonian), sedangkan spiritual pikiran (rasio) diam (pasif) dan hati (pusat jagad kecil) akan aktif, membuka dengan alam semesta yang kompleks (jagad besar) bersifat kodrati, memancarkan suasana kedalaman mana dalam memahami kehidupan penuh dengan keajaiban. ${ }^{2}$

Meskipun spiritual tidak bisa dipahami dan dijelaskan dengan ilmu modern tetapi dapat dirasakan. Untuk itu disinilah pentingnya memahami ilmu dan kompleksitas kehidupan dengan kecerdasan spiritual sehingga dapat membangun harapan dari cahaya spiritual untuk kemajuan ilmu hukum ke depan yang lebih utuh (holistik) sehingga dapat menjadi salah satu solusi dalam memecahkan permasalahan di bidang ilmu hukum.

Berdasarkan uraian tersebut yang menggunakan pendekatan konseptual maka dirumuskan masalah bagaimana pengembangan epistemologi ilmu hukum berbasis transendental.

\section{METODE PENELITIAN}

Metode penelitian yang digunakan dalam penelitian ini merupakan pendekatan normatif atau conseptual approach, dengan melakukan pendekatan integrasi keilmuan antara perspektif ilmu hukum dengan kajian filsafat ilmu. konsep yang dikaji dalam penulisan ini adalah konsep epistimologi ilmu hukum.

\footnotetext{
2 Absori, Materi Kuliah Filsafat Ilmu, Program Doktor Universitas Muhammadiyah Surakarta, 2015.
} 


\section{PEMBAHASAN}

\section{Pengembangan Epistemologi Ilmu Hukum Berbasis Transendental}

Pengembangan ilmu hukum dalam kegiatan ilmiahnya bertolak dari sejumlah asumsi dan bekerja dalam kerangka dasar umum atau general basic framework tertentu yang mempedomani kegiatan ilmiah dan memungkinkan berlangsungnya diskursus (diskusi dan komunikasi secara rasional) dalam lingkungan komunitas ilmuwan hukum. Perangkat asumsi inilah yang dapat disebut sebagai paradigma dalam hukum. Istilah paradigma dipopulerkan oleh Thomas S. Kuhn dalam The Structure of Science Revolutions (1962-1970). ${ }^{3}$ Dengan demikian dalam bidang ilmu hukum paradigma dimaknai sebagai pandangan yang mendasar tentang ilmu hukum yang seharusnya dipelajari dan metode ilmiah yang digunakan. ${ }^{4}$ Terdapat beragam paradigma sebagai pendekatan dalam pengembangan ilmu, seperti positivisme, postpositivisme, holistik dan transendental.

Dimensi transendental dalam postmodernisme dapat dilihat pada jangkauan yang lebih luas yang berupa agama, etika, dan moralitas, yang tidak lagi dipahami dalam satu aspek saja, yaitu aspek yang terkait dengan persoalan teologi dan keinginan semata, tapi lebih dari itu persoalan nilai-nilai tersebut dapat didialogkan dengan persoalan pengembangan keilmuan, sosial, budaya, ekonomi, dan hukum. Krisis masyarakat barat yang dianggap sebagai kegagalan peradaban modern karena pemikiran modern memisahkan spiritualisme dengan segala aspeknya dalam satu kesatuan kehidupan dan pembangunan peradaban manusia. ${ }^{5}$

Adanya krisis paradigma yang dibangun positivisme dunia barat telah mengguncang keyakinan manusia terhadap peradaban ilmu hukum sebagai representasi dari realitas yang utuh. Krisis paradigma bahkan telah memunculkan kegelisahan-kegelisahan baru hakekat alam dalam kehidupan, hubungan manusia dengan alam serta hubungan manusia dengan Sang Pencipta. Berawal dari kegelisahan itulah pada

\footnotetext{
${ }^{3}$ Bernard Arief Sidharta, Ilmu Hukum Indonesia: Upaya Pengembangan Ilmu Hukum Sistematik yang Responsif Terhadap Perubahan Masyarakat, Genta Publising, Yogyakarta, 2013, h. 71

${ }^{4}$ Absori, Op.Cit., h. 4, lihat juga dalam Absori, Kelik Wardiono, Saepul Raochman, Hukum Profetik, Kritik terhadap Paradigma Hukum Non-Sistematik, Genta Publising, Yogyakarta, 2015, h. 30-33.

5 Ibid.
}

gilirannya muncul kesadaran untuk meninggalkan cara pandang reduksionalitik dan atomistis yang sering diidentikan dengan metode ilmiah, dan seiring dengan itu perlu dihadirkan paradigma baru sebagaimana pandangan Fritjof Capra yaitu pemikiran paradigma holistik atau holistic paradigm, agar ilmu hukum bisa tampil sebagai sebenarnya ilmu atau genuine science. ${ }^{6}$

Kritik lain secara filosofis dan sosiologis terhadap aliran pemikiran hukum positivisme telah dikemukakan sejak kelahirannya. Misalnya, Charles Samport dalam karyanya Disorder of Law, yang sejatinya hukum positivisme tersebut merupakan tonggak sejarah pengakuan terhadap kepastian hukum. Dalam ranah Das Sollen, kodifikasi dan unifikasi hukum untuk menjamin adanya kepastian tekstual. Tetapi, bukti yang terjadi di tingkat Das Sein adalah penuh ketidakteraturan atau disorder, penuh ketidakseragaman atau disuniformity. Karena itu, tidak mungkin mempelajari hukum secara liniear atau tunggal. Pemahaman hukum secara terpadu dan sistemik merupakan keniscayaan yang perlu peninjauan kritis.

Mengapa pendekatan terpadu atau sistemik diperlukan? Jawab Charles Samport adalah karena kepastian dan keteraturan hukum tidak dapat melepaskan dirinya dari hubungan-hubungan sosial yang berbasis pada hubungan kekuatan antara institusi yang satu dengan institusi lain atau power relation. Pandangan ini mendapatkan tempat ketika Satjipto Rahardjo mengajukan model pendekatan hukum progresif. ${ }^{7}$

Corak spiritual dalam alam postpositivisme dapat dilihat pada jangkauan yang lebih luas yang berupa agama, etika, dan moralitas. Agama, etika dan moralitas tidak lagi dipahami dalam satu aspek saja, yaitu aspek yang terkait dengan persoalan teologi dan keinginan semata yang dapat dilihat melalui doktrindoktrin dan peribadatan, tapi lebih dari itu persoalan nilai-nilai tersebut dapat didialogkan dengan persoalan pengembangan keilmuan, sosial, budaya, ekonomi, dan hukum. Sebab krisis masyarakat barat yang dianggap sebagai kegagalan peradaban modern karena pemikiran modern telah memisahkan

${ }^{6}$ Sudjito, Ilmu Hukum Holistik, Gajah Mada University Press, Yogyakarta, 2014, h. 10.

${ }^{7}$ Qodry Azizy dkk, 2012, Menggagas Hukum Progresif di Indonesia, Pustaka Pelajar kerjasama dengan IAIN Walisongo dan Program Doktor Undip, Semarang, h. 14. 
spiritualisme dengan segala aspeknya dalam satu kesatuan pembangunan peradaban yang dibangun.

Dalam alam postpositivisme, perspektif spiritual dengan segala aspeknya seperti keagamaan, etika, dan moral diletakkan sebagai bagian yang terpisah dari satu kesatuan pembangunan peradaban modern. Karena itu, hukum modern dalam perkembangannya telah hilang unsur yang esensial yang berupa nilai transedental. Hal ini terjadi sebagai akibat cara berpikir yang didasari dari pandangan keduniaan yang diurus oleh kaisar dan keagamaan yang diserahkan pada tokoh agama (pendeta, rahib, dan ulama). Cara berpikir seperti itu muncul bersamaan dengan runtuhnya kekuasaan Romawi dan berdirinya negara-negara bangsa di Eropa melalui Perjanjian West Phalia tahun 1648 M yang dianggap sebagai awal kebangkitan Eropa, yang memunculkan etika Protestan sebagai kekuatan yang mempengaruhi kapitalis Barat

Berangkat dari adanya kegagalan peradaban barat mulai mencari alternatif pemikiran yang memadukan antara rasio dengan hati/kalbu dengan mengenalkan berfikir spiritual atau spiritual tinking sebagaimana pandangan Danah Zohar dan Ian Marshall, yang dikutip Absori ${ }^{8}$ dengan menggunakan pendekatan kecerdasan spiritual atau spiritual quition, yang akan diperoleh kecerdasan yang paling sempurma atau ultime intelegent, dilakukan dengan cara menerabas garis-garis formalisme atau existing rule dan transendental, sehingga akan dapat diperoleh pemikiran baru yang mendekati kebenaran yang hakiki atau the ultimate truth. Di mana manusia memerlukan Spiritual Quotient yang merupakan alat bagi manusia untuk dapat membangun berbagai perspektif baru dalam kehidupan, mampu menemukan cakrawala luas pada dunia yang sempit dan bisa merasakan kehadiran Tuhan tanpa bertemu dengan Tuhan.

Pekerjaan atau aktifitas berpikir manusia itu akan menghasilkan pengetahuan dan pada tahapan tertentu akan menjadi ilmu. Ilmu inilah yang sangat penting dalam kehidupan manusia, ilmu itu pula yang dapat menghantarkan manusia memenuhi kebutahan hidup, meningkatkan kualitas hidupnya, dan mengemban amanat hidupnya sebagai khalifah di muka bumi. Dalam kehidupan, manusia memerlukan kebenaran, sebuah term yang ditujukan pada suatu yang tepat dan benar, yang diterima oleh pikiran/akal yang sehat, dan

\footnotetext{
${ }^{8}$ Absori, Op.Cit., ... Hukum Profetik, h. vi.
}

sesuai dengan kehendak dan ketetapan Tuhan, yang dapat diketahui baik dari wahyu maupun sunatullah.

Dalam perjalanan sejarah dan pengalaman empirik, sering dijumpai adanya pandangan bahwa kebenaran ilmu hanya untuk ilmu, bahkan lebih pragmatis lagi, yakni tergantung kepada berbagai kepentingan, termasuk kepentingan ideologi dan politik, Kebenaran ilmu menjadi buta karena para ilmuwan penemunya tak beretika dan tak bermoral, sehingga tidak heran kalau hasil temuannya digunakan untuk kepentingan yang tidak bertanggungjawab, ilmunya menjadi tidak bermanfat dan mendatangkan bencana kemanusiaan, sedangkan ajaran moral mengajarkan sebaik-baiknya manusia adalah yang bermanfaat bagi manusia lain.

Namun demikian ilmu dan pengembangannya tidak bisa lepas dari etika dan moral. Sekalipun sering dicampuradukan dalam penggunaannya, tetapi persoalan baik-buruk, sopan, jujur, patriotik, solider adil, teguh pada pendirian yang benar, mencintai keindahan, dan lain lain, kesemuannya akan berkaitan dalam pengembangan ilmu dan perilaku keseharian seorang ilmuwan. Karena itu pengembangan ilmu menuntut value, etika dan moralitas memanusiakan manusia. Demikian juga amat dibutuhkan produk seni berupa keindahan dan keharmonisan, serta moralitas yang mensucikan batin.

Dalam situasi hipotesis yang dilematis harus dipahami bahwa kebenaran merupakan suatu nilai, demikian juga kebaikan dan kemaslahatan. Ketiganya tidak bisa dilepas dalam bagian-bagian tersendiri, tetapi berkaitan yang menampilkan pandangan bahwa ilmu yang tidak bebas nilai. Seorang ilmuwan dalam menyampakan kebenaran tidak bisa lepas dari tata nilai keyakinan dan intiusi hati nurani yang menyuarakan etik kemanusiaan dan moral, serta nilai-nilai yang digali dari relung-relung kehidupan masyarakat (budaya) dan kemanfaatannya untuk umat manusia.

Kebenaran spiritual selama ini sengaja atau tidak disengaja dijauhi oleh para ilmuwan, karena dianggap lekat dengan wilayah kajian teologi atau agama. Pertanyaan muncul, kenapa Allah menurunkan agama yang mengajarkan nilai-nilai kebenaran kebaikan dan keindahan. Lebih rumit lagi pemahaman dan penafsiran antar agama terhadap suatu nilai seringkali berbeda. Inilah barang kali pentingnya dilakukan dialog agama atau nilai, dalam rangka mencari dan menghubungkan titik- 
titik persamaan menjadi konfigurasi tatanan nilai yang amat dibutuhkan manusia yang mendambakan terciptanya ketenteraman dan kedamaian kehidupan manusia.

Ilmu tidak boleh tinggal diam untuk mendialogkan persoalan nilai, dan tidak boleh menganggap bahwa persoalan nilai dianggap bukan wilayahnya. Ilmu perlu didorong lagi untuk memasuki wilayahwilayah seperti itu dan memfasilitasi dalam bentuk memberikan sumbangan kelebihan (metodologi) yang dimiliki, dalam rangka untuk melakukan konvergensi atau titik temu antara persoalan kebenaran ilmu dan kebenaran ilahiah yang vertikal. Inilah tugas kita bersama sebagai seorang ilmuwan.

Alam pemikiran spiritual Islam misalnya, tumbuh tidak lepas dari proses asimilasi dan akulturasi antara kebudayaan Islam dan kebudayaan Yunani. Dalam Al-Qur' an sendiri tidak ditemukan kata filsafat atau al-falsafah, karena Al-Qur'an menggunakan bahasa Arab asli, sementara al-falsafah merupakan bahasa arab bentukan yang sudah terpengaruh kata filsafat dari bangsa Yunani. Filsafat sebagai ilmu hakikat, dalam Al-Quran disebut dengan kata hikmah, atau alhikmah. Al-Quran berisi kumpulan tertulis mengenai wahyu Tuhan, sedang hikmah atau filsafat adalah ilmu mengenai hakikat sesuatu. ${ }^{9}$

Menurut Ali Ashraf sebagaimana dikutip Turiman, ${ }^{10}$ Ilmu berangkat dari nilai atau moral AlQur'an dan Hadits, yang mana keduanya bukan hanya menampilkan ayat-ayat atau bukti kebenaran, tetapi juga hudan atau pedoman kebijakan, juga rakhmah atau anugerah Allah. Karena itu ilmu bukan hanya mencari kebenaran yang didasarkan pada penalaran dan diskursus, melainkan juga mencari kebijakan, kemaslahatan, ridha dan kasih sayang Allah. Dalam perspektif Islam, ilmu secara aksiologis tidak hanya sekedar untuk ilmu, tetapi lebih dari itu ilmu harus bermanfaat untuk kemaslahatan, yakni kepentingan orang banyak. Ilmu ada dan ditemukan di dalam alam kehidupaan masyarakat Manusia disuruh untuk menggunakan potensinya, yakni akal dan hati untuk memahaminya. Dalam Islam akal atau al-aql menempati kedudukan yang teramat penting, di samping hati atau kalbu dan indera yang lain. Karena

\footnotetext{
${ }^{9}$ Musya Asy'arie, Filsafat Islam Suatu Tinjauan Ontologis, dalam Filsafat Islam suatu Tinjauan Ontologis, Epistemologis, Aksiologis, Historis dan Prospektif, Lembaga Studi Filsafat Islam, Yogyakarta, 1992, h. 14.

${ }^{10}$ Turiman, Memahami Hukum Progresif Satjipto Rahardjo dalam Paradigma Thawaf, Undip, Semarang, 2010, h. 23.
}

itu firman Allah yang pertama kali turun melalui Nabi Muhammad SAW adalah Surat Al-Alaq yang dikenal dengan Surat Iqra' (membaca), disebutkan dalam Al-Qur'an, Bacalah dengan menyebut nama Tuhanmu yang menciptakan, Bacalah dan Tuhanmu yang paling pemurah. ${ }^{11}$

Dengan potensi yang dimiliki, manusia diperintahkan membaca kekuasaan Allah yang ada di alam ini, sebagaimana disebutkan dalam Al-Quran: Sesungguhnya dalam penciptaan langit dan bumi, dan silih bergantinya malam dan siang terdapat terdapat tanda-tanda bagi orang yang berakal. ${ }^{12}$ Diantara tandatanda kekuasaan Allah, ialah menciptakan langit dan bumi dan bangsa berlain-lain bahasa dan warna kulit. Sesungguhnya yang demikian ini terdapat tandatanda bagi orang yang mengetahui (berilmu). ${ }^{13}$

Ilmu dalam Islam di samping bisa digali berdasarkan Al-Quran dan Hadits juga terdapat Maslahat Mursalah, yang merupakan sumber hukum tambahan berdasarkan penelitian empiris atau istiqra, yang diperoleh dari penomena alam dan perilaku masyarakat, ditemukan dengan tujuan untuk kemaslahatan kehidupan manusia. Hal tersebut didasarkan pada Al-Quran yang menyebutkan, Dan tiadalah Kami mengutus kamu (nabi), melainkan untuk menjadi rakhmat bagi alam semesta. ${ }^{14}$ Kemaslahatan dapat ditangkap secara jelas oleh orang yang mempunyai dan mau berfikir, sekalipun dalam khasanah pemikiran Islam terdapat perbedaan dalam memahami hakikat maslahat. Perbedaan tersebut bermula dari perbedaan kemampuan intelektualitas orang per orang dalam menafsirkan ajaran Islam yang terdapat dalam Al-Quran dan Hadits, dimana masing-masing ahli pikir mempunyai keterbatasan, sehingga tidak mampu memahami hakikat maslahat secara sama, karena adanya perbedaan yang bersifat temporal dan kondisi daerah (lokal) yang tidak sama.

Dimensi spiritual bisa dilihat pada ajaran yang paling dasar, yakni aqidah, yang mengajarkan pemahaman hubungan antara manusia dengan alam dan dengan Tuhannya. Manusia dan alam pada hakikatnya adalah makhluk yang bersifat fana, sementara Tuhan adalah penguasa atas alam semesta beserta isinya atau robbul alamin yang bersifat kekal atau baqa. Kebahagiaan terbesar seorang muslim

\footnotetext{
${ }^{11}$ QS. Al-Alaq, ayat 1 dan 3.

12 QS. Ali-Imran, ayat 190.

${ }^{13}$ QS. Ar-Ruum, ayat 22.

${ }^{14}$ QS. Al-Anbiya, ayat 107.
} 
mana kala dia mampu pasrah secara tolalitas mematuhi perintah (hukum-hukum) Allah yang bersifat kodrati atau sunnahtullah, baik yang bersifat umum ataupun yang terperinci, sebagai konsekwensi dari pengakuannya bahwa Allah Maha Esa, penguasa segalanya, dan segala makhluk bergantung padanya. ${ }^{15}$

Perspektif spiritual Ilmu, termasuk ilmu hukum bukan hanya didasarkan pada kebenaran yang qauliyyah, yang tingkat kebenarannya pada taraf haqq al-yakin, yang terhimpun dalam Al-Qur'an dan Hadits, tetapi juga berdasarkan kebenaran yang diperoleh dengan kemampuan potensi manusia melalui ulum naqliyyah, yakni perenungan, penalaran dan diskursus yang berkembang di masyarakat. Manusia menggali, mengolah dan merumuskan ilmu dengan tujuan tidak semata untuk ilmu tetapi juga untuk kebijakan, kemaslahatan masyarakat luas, dengan ridha, dan kasih sayang Allah.

Kita sekarang hidup, seperti ditunjukkan oleh Fritjof Capra, sebagaimana dikutip oleh Muhammad Ikhsan ${ }^{16}$ dalam suatu masa turning point. Ketidakmampuan kita untuk kembali melihat kehidupan manusia dengan pandangan yang utuh, menurut Capra, menyebabkan terjadi krisis dalam dimensi-dimensi intelaktual, moral, dan spiritual manusia. Dalam kehidupan manusia, memang potensi akal dan budinya telah mendorong manusia untuk mencari, mendekati, dan menemukan kebenaran. Ada yang hanya mampu mendekati dan menemukan kebenaran pada tahap kulitnya saja (kebenaran formal), tetapi ada pula yang tidak puas terhadap kebenaran itu, mereka mengharap, mencari, dan menemukan, atau setidak-tidaknya mendekati kebenaran sejati, kebenaran materiil, kebenaran substansial, kebenaran mutlak, kebenaran hakiki, kebenaran ilahiah, atau apapun itu namanya

Ketinggian tingkat kecerdasan lahir-batin selanjutnya dipahami dengan menggunakan pemikiran ilmu pengetahuan menurut tokoh ilmuan Islam Imam al-Ghazali dalam bukunya yang berjudul Ihya' Ulumiddin dan telah diterjemahkan dalam bahasa Indonesia oleh Moh Zuhri. ${ }^{17}$ Dasar pemikiran peneliti menggunakan pemikiran Imam al-Ghazali

\footnotetext{
${ }^{15}$ QS. Al-Ikhlas, 112: 1-2.

${ }^{16}$ Muhammad Ikhsan, "Epistemologi Mencari Kebenaran dengan Pendekatan Filsafat Transenden”, Proceding Seminar, Universitas Muhammadiyah Surakarta, 2015.

${ }^{17}$ Imam al-Ghazali, Ihya'Ulumiddin: terjemahan oleh Moh. Zuhri, Semarang, Asy Syifa, 2003, h. 6-7.
}

dalam bukunya Ihya' Ulumiddin adalah merupakan sebuah hasil kontemplasi dialektika yang terus menerus tanpa henti untuk mencurahkan pemikiran dalam rangka menemukan ide gagasan paradigma ilmu transendental yang diyakini mampu menjawab problematika ilmu hukum di Indonesia.

Menurut pemikiran Imam al-Ghazali ilmu pengetahuan manusia itu pada dasarnya dibagi menjadi dua, yaitu ilmu pengetahuan lahir dan ilmu pengetahuan batin. Yang dimaksud ilmu pengetahuan lahir adalah ilmu pengetahauan yang berhubungan dengan amal anggota badan, sedangkan ilmu pengetahuan batin adalah ilmu pengetahuan yang berhubungan dengan amal hati dan yang berjalan atas anggota badan baik yang adat atau ibadat.

Pemikiran Imam Al-Ghazali banyak diambil dari ayat-ayat Al-Quran dan Al-Hadist yang berhubungan dengan keutamaan ilmu pengetahuan lahir-batin bagi manusia, seperti terdapat dalam Q.S. Ali 'Imran: 18 yang artinya, Allah menyatakan bahwasanya tidak ada Tuhan melainkan Dia, yang menegakkan keadilan. Para malaikat dan orang-orang yang berilmu (juga menyatakan yang demikian itu). Dalam Al-Quran telah disebutkan tentang pengaruh ilmu pengetahuan lahir-batin bagi manusia. Dengan ilmu pengetahuan yang dimiliki, maka Allah akan memberikan kemuliaan derajat untuk manusia itu, seperti terdapat dalam QS. Al Mujadilah ayat 11 yang artinya: Niscaya Allah akan meninggikan orangorang yang beriman diantaramu dan orang-orang yang diberi ilmu pengetahuan beberapa derajat.

Dimensi basis transendental digambarkan dalam Hukum Profetik dengan konsep humanisasi, liberasi dan transendensi oleh Kuntowijoyo ${ }^{18}$ digunakan dalam membahas ilmu pengetahuan sosial secara umum. Dalam hal ini unsur transendensi harus menjadi dasar unsur yang lain dalam pengembangan ilmu dan peradaban. Metode pengembangan ilmu dan agama yang disebut sebagai profetik mendasarkan pada Al-Quran dan Sunnah merupakan basis utama dari keseluruhan pengembangan ilmu pengetahuan. Profetik yang dipelopori Kuntowijoyo menyerupai konsep integrasi ilmu dan agama oleh Amin Abdullah, konsep Islamisasi ilmu menurut Naquib al-Attas dan Ismail Raji al Faruqi. Profetik kemudian juga menjadi

18 Henddy Shri Ahimsa Putra, "Paradikma Profetik, Mungkinkah, Perlukah”, Makalah, UGM, Yogyakarta, 2011. Lihat juga dalam Absori, Kelik Wardiono, Saephul Rochmanl, Hukum Profetik, 2015. 
paradigma ilmu hukum di Indonesia. Dengan konsep humanisasi, liberasi, dan transendensi ilmu hukum dibangun guna untuk menemukan epistemologi ilmu hukum yang mampu menjawab problematika hukum di Indonesia. Humanisasi merupakan usaha untuk mengangkat kembali martabat manusia melalui jalan Tuhan. Liberasi merupakan ilmu hukum yang memiliki tanggung jawab profetik untuk membebaskan manusia dari ketidakbaikan. Transendensi merupakan bentuk ilmu hukum yang mengandung unsur-unsur dasar keimanan kepada Allah, sebagaimana pendapat Khudzaifah Dimyati. ${ }^{19}$

Hukum profetik memandang dasar ilmu pengetahuan adanya petunjuk yang sifatnya intuitif (iman) atau apriori, Karena sifatnya yang intuitif maka pengetahuan bermula dari kemampuan reseptif manusia terhadap apa yang dilimpahkan dari wahyu atau hidayah, karena itu paradigma profetik menolak pandangan keraguan-kepastian Descrates atau keraguan-ketidakpastian Derida. Dalam paradigma profetik mengembangkan adanya relasi pengetahuan dalam diri manusia yang ditimbulkan dari organorgan pemahamannya, diantaranya; indera atau sense baik indera lahir maupun batin, inspirasi atau intuisi yang terletak dalam hati atau jantung, rasio sebagai fungsi berfikir dan wahyu yang diturunkan kepada nabi. Konsekuensi dari hal tersebut adalah adanya integritas profetik yang merupakan suatu kesadaran emansipatoris: transendensi, humanisasi, liberasi dan aktivisme historis: Penghayatan atau pelibatan pikiran dan perasaan pada sesuatu yang diyakini (sebagai basis dari semua etos/nilai); Pengabdian; Etos kerja keilmuan; Etos kerja kemanusiaan, yang terdiri dari: kejujuran; keseksamaan/ketelitian; kekritisan dan penghargaan. ${ }^{20}$

Hukum profetik berakar pada kehendak Allah kepada makhlukNya yang diturunkan melalui Nabi dan RosulNya, para Mualim dan Aulia yang senantiasa istiqomah dan berpegang teguh pada garis ilahiyah atau sunnatullah. Sunnatullah merupakan basis filsafat hukum alam atau natural law dijabarkan melalui ayat-ayatNya baik yang tertulis (Kitab dan Sunnah) maupun yang terjabarkan dalam alam semesta dan realitas kehidupan. Hukum profetik

${ }^{19}$ Khudzaifiah Dimyati, Pemikiran Hukum: Kontruksi Epistimologis Berbasis Budaya Hukum Indonesia, Genta Publishing, Yogyakarta, 2014, h. 135-139.

${ }^{20}$ Absori, Kelik Wardiono, Saephul Rachman, Op.Cit., h. 396-397. ditujukan untuk pegangan hidup manusia mencapai kebahagiaan dunia dan akherat. Hukum profetik hanya dapat dipahami dengan pendekatan holistik yang melihat manusia dan kehidupanya dalam wujud yang utuh, tidak bersifat materi tetapi ruhaniyah atau inmateral. Hukum profetik tidak dapat dipisah antara jasad fisik atau formal dan nilai-nilai transendental. ${ }^{21}$

Dengan demikian justifikasi pengembangan epistemologi ilmu hukum berbasis transendental hanya bisa dipahami dengan pendekatan holistik yang melihat manusia dan kehidupannya dalam wujud yang utuh, tidak semata bersifat materi tetapi ruhaniyah atau inmateral. Ilmu hukum transendental tidak dapat dipisah antara jasad fisik atau formal dan nilai-nilai transendental. Justifikasi ilmu hukum transendental semata yang diburu adalah demi keadilan berdasar kebenaran atas kuasa Allah, Dzat yang Maha Kuasa, penentu hidup dan kehidupan manusia. Ilmu hukum transendental beroreintasi pada kemaslahatan manusia sebagai wujud dari kasih sayang untuk makhluknya.

\section{PENUTUP}

Pertama, Terdapat kecenderungan kuat untuk memahami ilmu hukum tidak hanya dipandang dari segi normatif yang positivis, tapi lebih dari itu ilmu hukum harus dilihat dalam wajah yang utuh menyuruh. Kajian seperti itu mulai terasa dan mendapat tempat alam postpositivis.

Kedua, ilmu hukum berbasis transendental menekankan pada pendekatan integrasi antara sains dan nilai-nilai dalam berbagai bentuk dan pandangan. Dalam hal ini, ilmu hukum transendental hanya bisa dipahami dengan pendekatan holistik yang melihat manusia dan kehidupannya dalam wujud yang utuh, tidak semata bersifat materi tetapi ruhaniyah atau inmateral. Manusia menggali, mengolah dan merumuskan ilmu dengan tujuan tidak semata untuk ilmu tetapi juga untuk kebijakan, kemaslahatan masyarakat luas, dengan ridha, dan kasih sayang Allah.

Upaya untuk mengkaji dan memahami hukum harus lebih menekankan hal yang sifatnya substantif dan transendental dengan mendasarkan pada fakta sosial yang tidak lepas dari nilai-nilai agama, etik dan moral, tetapi tanpa mengenyampingkan kekritisan sebuah teori yang ditawarkan sebagai iktihad manusia. Pada pemahaman hukum postpositivisme, spiritualisme dapat dipahami dalam berbagai makna

\footnotetext{
${ }^{21}$ Ibid., h. xi.
} 
sebagai spirit (ruhaniyah) yang berkaitan dengan substansi ajaran agama dan hal- hal yang berhubungan dengan etika dan moral.

Upaya untuk mendiskusikan kembali secara intens dan mendalam persoalan hukum, agama, etik dan moral menjadi teramat penting. Kegiatan seperti itu dapat membuktikan bahwa sesungguhnya tidak lagi diperlukan ketegangan antara kepercayaan kepada Tuhan dengan ilmu hukum. Melalui upaya seperti itu dapat memperlihatkan bahwa kepercayaan kepada Tuhan sesungguhnya akan mendukung hasil-hasil pengembangan ilmu hukum itu sendiri. Kepercayaan dimaksudkan selaras dengan konsep sunatullah baik yang ada di hamparan alam semesta maupun yang ada pada diri manusia yang juga berlaku bagi dirinya sunatullah-Nya.

\section{DAFTAR PUSTAKA}

Absori, "Epistimologi Ilmu Hukum Transendental dan Implementasinya dalam Pengembangan Program Doktor Ilmu Hukum", Prosiding, Seminar Nasional di Universitas Muhammadiyah Surakarta, 11 April 2015. ,2015, Materi Kuliah Filsafat Ilmu, Program Doktor Universitas Muhammadiyah Surakarta. Absori, Kelik Wardiono, Saepul Raochman, 2015, Hukum Profetik, Kritik Terhadap Paradigma Hukum Non-Sistematik, Yogyakarta: Genta Publising.
Al-Ghazali, Imam, 2003, Ihya'Ulumiddin: terjemahan oleh Moh. Zuhri, Semarang: Asy Syifa.

Asy'arie, Musya, 1992, Filsafat Islam Suatu Tinjauan Ontologis, Dalam Filsafat Islam Suatu Tinjauan Ontologis, Epistemologis, Aksiologis, Historis dan Prospektif, Yogyakarta: Lembaga Studi Filsafat Islam.

Azizy, Qodry dkk, 2012, Menggagas Hukum Progresif di Indonesia, Semarang: Pustaka Pelajar kerjasama dengan IAIN Walisongo dan Program Doktor Undip Semarang.

Dimyati, Khudzaifiah, 2014, Pemikiran Hukum: Kontruksi Epistimologis Berbasis Budaya Hukum Indonesia, Yogyakarta: Genta Publishing.

Ikhsan, Muhammad, 2015, "Epistemologi Mencari Kebenaran dengan Pendekatan Filsafat Transenden", Proceding Seminar, Universitas Muhammadiyah Surakarta.

Putra, Henddy Shri Ahimsa, 2011, "Paradikma Profetik, Mungkinkah, Perlukah", Makalah, Yogyakarta: UGM.

Sidharta, Bernard Arief, 2013, Ilmu Hukum Indonesia: Upaya Pengembangan Ilmu Hukum Sistematik yang Responsif Terhadap Perubahan Masyarakat, Yogyakarta: Genta Publising.

Sudjito, 2014, Ilmu Hukum Holistik, Yogyakarta: Gajah Mada University Press.

Turiman, 2010, Memahami Hukum Progresif Satjipto Rahardjo Dalam Paradigma Thawaf, Semarang: Undip. 